\title{
INTERPERSONAL RELATIONS IN SCHOOL
}

\author{
Dr. Siniša Opić, Faculty of Teacher Education, University of Zagreb, Croatia \\ E-mail: sinisa.opic@ufzg.hr
}

ARTICLE INFO

Original Article

Received: October, 26.2016.

Revised: November, 15.2016.

Accepted: November, 18.2016.

doi:10.5937/IJCRSEE1602009O

UDK

37.064.1/.3(497.5)"2016"

316.472 .42

\section{A B S T R A C T}

As part of the scientific project titled "The Curriculum of Social Competences and Relations in School", the aim of this paper is to examine the quality of interpersonal relations between teachers and pupils. On a sample of 432 teachers from 20 towns, 35 primary schools in the Republic of Croatia, and 432 pupils, it was confirmed that there is a difference in the appraisal of the quality of their interpersonal relations. Although the overall quality of interpersonal relations between pupils and teachers is at a moderately satisfactory level, pupils still appraise the quality of interpersonal relations lower than their teachers. In view of latent dimensionality, a factor questionnaire structure was used (14 variables; ordinal type) and two main components (subscales) determined: didactic support and interaction, and rough verbal and physical treatment. As part of the differential draft of our research, no gender differences were established (between female and male teachers) in the appraisal of the quality of interpersonal relations with pupils (on two subscales). The correlation analysis confirmed a low negative statistically significant correlation between the years of service and the subscale rough verbal and physical treatment $($ Rho $=-0.101)$. In view of the subscale of rough verbal and physical treatment between pupils and teachers, such results on a negative correlation imply that older teachers, as opposed to their younger colleagues, use more corporal punishment in schools, treat pupils rudely, use nasty and impolite words, and call pupils insulting names.

(C) 2016 IJCRSEE. All rights reserved.

\section{INTRODUCTION - INTERACTION AS SINGULARITY}

From the appearance of the first hominids to modern humans, the ability to live in a community is an ability par excellence. We can thank our ability to co-exist, cooperate, learn, share, help, and play with other people for our evolutionary development. Other people interact with us and leave an indelible mark on us. And this is not unusual since a certain mutual relationship and interaction (from our viewpoint socio) actually transcends ourselves and is characteristic of the whole life on earth.

In the animal kingdom, animals that live in communities have a better chance of survivCorresponding Author
Dr. Siniša Opić, Faculty of Teacher Education, Univer-
sity of Zagreb, Croatia E-mail: sinisa.opic@ufzg.hr

\footnotetext{
This work is licensed under a Creative Commons Attribution - NonCommercial - NoDerivs 4.0. The article is published with Open Access at www.ijcrsee.com
}

ing as a species. Their ability to hunt, protect themselves from predators, and reproduce is increased through such a relationship. From the position of positivism (Auguste Comte, 1798-1857) and an explanation of the connection and mutual relationship of the social and natural sciences, we can suppress socio as an interaction of sorts to the molecular/atomic level. Actually, the mentioned doctrine tells us that the laws that govern the social sciences (e.g., behaviour) are identical to the behaviour of matter (atoms, molecules). These are invariable laws that apply to everything. If we observe interaction from the aspect of particles, then we see the relationship/influence of one particle on others. At the atomic/ molecular level, basically this is interaction, relationship/co-relationship. The subatomic level is interaction between what are known as protons and electrons, and the interaction itself can be divided into electromagnetic interactions, weak atomic interactions and strong atomic interactions. Of course, the very structure of electrons, protons and other particles can be divided. In other words, they consist of quarks that are divided into three types and three "anti-types". A description of such in- 
teractions is provided by quantum mechanics (basically, these are quantum field theories, string theory...). In brief, quantum mechanics has more of a statistical character; it tells us about the probability of some events and describes objects in wave functions. Such an assumption, that particles are at the same time waves, was proven both in practice and theoretically (electron interference and the De Broglie relation). The singularity of interaction (the counterpart of socio) also consolidates gravitation as a fundamental force of nature. It is the universal force of objects to attract other object(s). It is always attractive (as opposed to electrically charged particles), although quite weak because particles are mostly held together by electrical forces that are stronger than the gravitational ones. This is interaction: the activity of one particle on another, that is, their mutual relationship.

Based on the principle of positivism, if we observe socio as interaction, then the basis of everything is some sort of interaction that has consequences on the behaviour of whoever is part of the interaction. Whether at the subatomic level or with humans, interaction (socio from the anthropological viewpoint) is a phenomenon that relates to singularity. Interaction observed from the position of the subatomic, atomic, molecular level or the level of the social world and/or from the universal cosmic aspect creates a vast spectrum of possibilities that create certain connections and co-relationships. Such co-relationships based on interactions create or have consequences on the behaviour of the component factors (parts) of such interactions. In the field of the social sciences that are based on the biopsychosocial structure of man, the study of interactions is the subject of much research within various scientific disciplines. However, on the grounds of the non-coherence, poor nomothetics, plausibility, and predictability of the social sciences, it follows that the results of research on the influence and consequences of such interactions are questionable. These results are mostly only declarative, and they do not deal with the field of education at a sufficient empirical level. However, the complexity of such research of interactions is also implied on the basis of positivism in the field of the natural sciences. It surpasses determinism, and emphasises probabilism, that is, the probability of certain outcomes of such interactions at the quantum level and in the behavioural field. Research of interactions/interpersonal relations in the field of education is extremely complex, because the prediction of someone's behaviour is not conditioned unambiguously but is a matrix that has an $\mathrm{x}$ of still unknown inputs, which form part of the final probable outcomes of someone's behaviour.

The amazing world of science often transcends reason and resembles more a fairy tale than common sense. In the field of the natural sciences, the pronounced asymptoticity of cognition guides scientists to examine various complex connections, interactions that are part of our understanding and vision of the micro and of the macro world. Further, there is a sort of compatibility between the functioning at the smallest (subatomic) and at the largest (known to us, cosmic) level, which is based on a series of known and still unknown interactions between the component parts of the subject matter of this research.

Interaction as singularity consolidates the laws in which the world as we know it functions. Often such laws are more difficult to see because they are at the subatomic, molecular level, while at the level of human behaviour they are there for further research. Pedagogy and other sciences that study the process of upbringing and education should acknowledge the results of research of the natural sciences in their active research of a series of aspects pertaining to interactions in education. The results of such research will advance the process of education and improve our understanding of ourselves.

\subsection{The teacher/pupil relationship}

Today, as we stand witness to the exponential development of technologies that have come to substitute interpersonal relations and where we see young people living in a virtual world, a world of their own avatars, the school is seeking answers about how to replace certain anomalies. The family as the basic building block of society is falling apart and the relations within it are often dysfunctional. The young find it harder and harder in today's neoliberalism to meet the expectations of society, of their parents and/or of themselves and are growingly exposed to alcohol and/or other addictive behaviours. Therefore, it is necessary to guide the modern school towards the components of both upbringing and interpersonal relations. Actually, the school role of upbringing and its social role have atrophied, since various social phenomena are peeping "through school doors and windows" and often enter in, for example in the form of aggression and violence and other types of socially 
unacceptable behaviour of pupils and teachers (Previšić, 2003, 16-17).

The modern school seeks answers to emphasise its efficiency and recognition in the preparation of young people for modern society. Every person has the need to live in the company of other people and to be accepted and to have a certain position in that society. Individuals have strong emotions-social emotions - that follow from that need (Furlan, $1967,160)$. As we pointed out in the introduction, social relationship is a type of evolution par excellence: observed through interaction it is singular, which is why schools, as their primary duty, should build the totality of the processes of upbringing and education on the foundation of high quality interpersonal relations.

One of the preconditions for a successful teaching process is a good relationship between the teacher and the pupil, although the said relationship actually envelops a triad of co-relationships by and between the teacher, pupil, and the parent. The relationship is not unambiguous, since it can be based on authoritarianism or authority. "It can be based on mutual trust but also on discomfort, even fear. Work on the relationship, that is, its true values, is the never-ending task of the teacher" (Marinković, 2008, 80). Consequences of the relationship between the teacher and the pupil leave a permanent imprint on the development of the pupil. In this sense, (Klarin, Lukić and Ušljeberka, 2003) shows that fear and distrust in the pupil as the result of his or her relationship with the teacher lead to what he refers to as the "six Rs":

1. Resentment occurs because we hurt pupils, we punish them without justification, humiliate and embarrass them before their schoolmates; it fuels the desire for revenge;

2. Resistance occurs because the pupil's human rights are threatened; sometimes there is ambivalent behaviour;

3. Rejection occurs when we manipulate pupils in a way to make them dependent on punishment and rewards; some of them satisfy their need for power through rebellion and refusal to co-operate;

4. Retreat on account of the teacher's fear; retreat and distancing; possible development of internalised behavioural problems;

5. Reluctance: pupils refuse to co-operate, they are idle and lose interest in school; this is reflected in their results and in loss of motivation;

6. Revenge takes place when pupils destroy school property; they compensate for the deteriorated relationship with the teacher.

The relationship between the teacher and the pupil, or the quality of the relationship, is connected with the pupil's success in school (Klarin, Lukić and Ušljeberka, 2003). The characteristics of a pupil are not a good predictor of his or her success outside the school, where a large part of the differences in accomplishments can be explained by the complex characteristics of the social structure of the school (Juul and Jensen, 2010, 46).

Further, the quality of interpersonal relations between the teacher and the pupil can be observed as part of the development of the pupil's creativity. Creativity is basically something inherent in anybody, but it is dependent on one's lifestyle-from prenatal, natal, preschool and school to old age-and on an individual's connections with his or her surroundings (Juul and Jensen, 2010, 46). Connection with one's surroundings can be observed as interaction with the surroundings, that is, interpersonal relations. It is interesting that the author shows that preschoolers are more creative than children who go to school, despite the extensiveness of pedagogic action. The reasons for this can be examined further from the perspective of interpersonal relations that dominate and develop in the preschool institution as opposed to school. The child's willingness and ability to co-operate is a cornerstone for the development of his or her personality and for the upgrading of what we refer to as the "survival strategy" (Glasser, W. and Jakovlev, B. (1999)). The teacher's persistence, patience, listening, and encouragement of the pupil's inclusion in the teaching process, and at the same time the teacher's action towards the pupil's education and development of his or her competences, create conditions essential for co-operation (Glasser, W. and Jakovlev, B. (1999)). Such co-operation, in the didactic sense, can be viewed as pedagogic leadership. Pedagogic leadership means influencing people with the intention of having them change their positions and behaviour (Glasser, W. and Jakovlev, B. (1999)).

The role of the teacher (according to Glasser, W. and Jakovlev, B. (1999)) includes a palette of pedagogic care that goes beyond the activities and relations in school to encompass the life and work of the pupil in its totality. The authors place emphasis on trust 
shown to the (class) teacher, which "assigns to the teacher the role of the first person who helps pupils and provides them with support and guidance".

Any quality interpersonal relationship between the teacher and the pupil is based on a good example. The teacher is a model of sorts for pupils in terms of his or her behaviour, learning, gestures, relations with other people. If "you expect pupils to be polite, then you should not lose your temper or be sarcastic towards them" (Glasser, W. and Jakovlev, B. (1999)). Therefore, we can talk about mirroring in terms of the behaviour of pupils and the behaviour of their teacher.

In describing the conditions for quality work in school, as the first condition, Glasser, W. and Jakovlev, B. (1999) singles out an encouraging and pleasant atmosphere in the classroom that is based on solid friendships between teachers and pupils, and between pupils, teachers, and the school staff. The author emphasises that the foundation of trust and friendship is that pupils can talk to teachers truthfully and without any reservations (ibid. 36). In Glasser's school of quality, successful teaching is based on solid relations, and relations are based on trust and respect, and then disciplinary problems (not incidents) will disappear (Klarin, 2006, 93).

Pianta, 1994 (according to Šimić-Šašić, S. and Sorić, I. , 2010) systematises six different types of possible relationships between the teacher and the pupil (child):

1. A dependent relationship, based on trust and reliability;

2. Positive involvement, based on care and communication;

3. A dysfunctional relationship, characterised by low inclusion, anger and difficulties;

4. An averagely functional relationship;

5. An anger-based relationship, characterised by frequent conflicts;

6. An uninvolved relationship, characterised by a low level of communication, absence of care, and anger.

With the aim of improving teacher-pupil interaction and ensuring the better school results of pupils, it is necessary to act on the variables of the stimulation of the professional development of teachers or of the improvement of various aspects of the teaching task (Huitt, 2003). The results of research are in conformity with the transaction model of the process of teaching/learning (Gossen, D. C. and Despotović, M., 1994), which emphasises the teacher's individual characteristics that affect not only the behaviour of the teacher in the classroom but also learning achievement.

The quality of the teacher/pupil relationship in our schools has not been sufficiently evaluated; it is actually part of the hidden curriculum, but it leaves an immense mark on the totality of the process of upbringing and education. Just as in other activities, we are not the same in terms of the quality of work that we perform. Just as there are successful and less successful cooks, hairdressers, doctors, so there are also differences between teachers. In line with the said difference, Brajša (1995) presents the dichotomy in effective and ineffective teachers (Figure 1).

\begin{tabular}{|c|c|}
\hline Effective teachers & Ineffective teachers \\
\hline $\begin{array}{l}\text { Ask questions as follows: } \\
\text { - What do we have to think } \\
\text { of? } \\
\text { How would you like to } \\
\text { do it? } \\
\text { - How can I help you? } \\
\text { is the rule? Can you } \\
\text { comply with the rule? } \\
\text { - Do you think that what } \\
\text { you are doing is good? } \\
\text { Can you change that? } \\
\text { That won't work in this } \\
\text { case; think of something } \\
\text { else. }\end{array}$ & $\begin{array}{l}\text { - Avoid conflicts and } \\
\text { discussions } \\
\text { - Put emphasis on the } \\
\text { correct answer } \\
\text { - Give a lot of } \\
\text { homework } \\
\text { - Often hold tests and } \\
\text { exams } \\
\text { - Draw up instructions } \\
\text { for tests } \\
\text { - Keep a distance } \\
\text { Phrases used: "It won't } \\
\text { work; all children from } \\
\text { this family are the same; } \\
\text { can't you see I don't have } \\
\text { time; I cannot do that for } \\
\text { everyone; he needs a } \\
\text { therapist and I can't help } \\
\text { him; nothing new, we } \\
\text { have already tried that..." }\end{array}$ \\
\hline
\end{tabular}

Figure 1. Categorisation into effective and ineffective teachers

The above categorisation of teachers shows that the stress of performance and effectiveness lies in interaction, the relationship between the teacher and the pupil, which, based on the above categorisation, rests on high-quality communication from a didactic standpoint.

Neill, S. and Mikulić, G.,1994 enumerates the differences between successful and unsuccessful teachers. A successful teacher is provocative and has clear and definite goals; he or she is organised and altrocentric. An unsuccessful teacher is unduly relaxed, does not have clear and definite goals, he or she is disorganised, wants to be the winner, is egocentric, is not a good associate and does not take care of himself or herself. The question arises about whether parents know what the teacher is like and whether they would replace him or her. It is clear that in state schools parents do not have an opportunity to choose the teacher, 
which is bad, because in this way the system protects those teachers who have missed their calling and who should not work with children.

It is worrisome that there are teachers who work in schools who do not have good relations with their pupils, and then pupils pass on such behaviour and develop it while growing up. Parents entrust their child, as the most valuable thing in their life, to the school (teachers). They have the right and responsibility to know how their children are treated, communicated with, how they behave... It is not worth emphasising grades and knowledge to the detriment of interpersonal relations. The mentioned competences and knowledge develop from the said singularity of interactions/ interpersonal relations.

The quality of relationships and classroom communication can also be observed through non-verbal communication that may be interpreted in several ways (Neill, S. and Mikulić, G.,1994). It is necessary to acquire knowledge and the ability to recognise one's own and other people's body language, since non-verbal communication can affect the establishment of quality interpersonal relations (see Andrilović and Čudina, 1988).

Table 1. Totality of behaviour of pupils and teachers

\begin{tabular}{|c|c|c|c|c|c|}
\hline \multirow[b]{2}{*}{$\begin{array}{c}\text { EMOTIONAL } \\
\text { SETTINGS }\end{array}$} & \multicolumn{3}{|c|}{ Behaviour of the teacher } & \multicolumn{2}{|c|}{ Behaviour of the pupil } \\
\hline & $\begin{array}{l}\text { Planning, realisation } \\
\text { of instruction }\end{array}$ & $\begin{array}{l}\text { Approach to } \\
\text { instruction }\end{array}$ & Methods & $\begin{array}{l}\text { School } \\
\text { results }\end{array}$ & $\begin{array}{c}\text { Emotional } \\
\text { security }\end{array}$ \\
\hline SENTIMENTAL & improvised & $\begin{array}{l}\text { Impulsive, } \\
\text { variable }\end{array}$ & $\begin{array}{l}\text { Free } \\
\text { individualis- } \\
\text { ation }\end{array}$ & $\begin{array}{l}\text { Depends on } \\
\text { ability, poor } \\
\text { success in } \\
\text { correlation } \\
\text { with } \\
\text { emotionally } \\
\text { insecure } \\
\text { children }\end{array}$ & $\begin{array}{l}\text { Poor, can be } \\
\text { good for } \\
\text { children who } \\
\text { identify with } \\
\text { the teacher }\end{array}$ \\
\hline $\begin{array}{l}\text { WARM: the teacher- } \\
\text { - listens carefully } \\
\text { - accepts the pupil's } \\
\text { emotions and } \\
\text { suggestions } \\
\text { - detects the pupil's } \\
\text { reactions; he/she } \\
\text { praises and } \\
\text { encourages them }\end{array}$ & $\begin{array}{l}\text { - } \text { responsible } \\
\text { - systematic } \\
\text { - activity- } \\
\text { oriented/planned } \\
\text { - clear explanation of } \\
\text { the plan } \\
\text { - explanation of } \\
\text { criticism }\end{array}$ & $\begin{array}{l}\text { Simultaneous, } \\
\text { imaginative }\end{array}$ & $\begin{array}{l}\text { Works best } \\
\text { in } \\
\text { discussions, } \\
\text { frontal } \\
\text { instruction } \\
\text { and free } \\
\text { individualisa } \\
\text { tion }\end{array}$ & $\begin{array}{l}\text { Very good } \\
\text { when } \\
\text { teaching } \\
\text { methods are } \\
\text { aligned with } \\
\text { the } \\
\text { characterist- } \\
\text { ics of pupils }\end{array}$ & $\begin{array}{l}\text { Very good } \\
\text { when balance } \\
\text { is established } \\
\text { between } \\
\text { freedom and } \\
\text { guidance of the } \\
\text { pupil }\end{array}$ \\
\hline 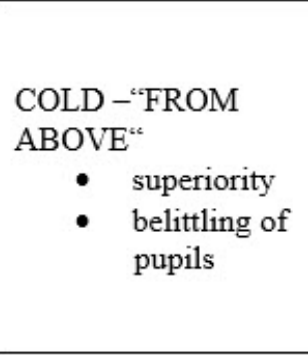 & $\begin{array}{l}\text { - arbitrary rules and } \\
\text { commands } \\
\text { - use of force and } \\
\text { coercion, even } \\
\text { when not necessary } \\
\text { - demands more than } \\
\text { the pupil can do } \\
\text { - non-constructive } \\
\text { criticism }\end{array}$ & $\begin{array}{l}\text { Routine, } \\
\text { unimaginative } \\
\text { and boring }\end{array}$ & $\begin{array}{l}\text { Best at } \\
\text { lectures }\end{array}$ & $\begin{array}{l}\text { Very good } \\
\text { in defined } \\
\text { tasks, } \\
\text { Poor results } \\
\text { for pupils } \\
\text { who are } \\
\text { negative }\end{array}$ & $\begin{array}{l}\text { Poor for most } \\
\text { children }\end{array}$ \\
\hline
\end{tabular}

An interesting comparison of the behaviour of teachers that affects the behaviour of pupils and their school results and emotional security is shown in Figure 1 (Klausmeier \& Goodwin, 1975, according to Brajša, BrajšaŽganec and Slunjski (1999)).

As is clear from Table 1, the behaviour of teachers is directly linked to the behaviour of pupils. The teacher is the director, scenographer, costume designer, producer, and an actor in the film of the life of each and every pupil. The film is about growing up, gaining experience, and preparing for adult life. Roles in the film are intertwined, but the act of creating the film is in the hands of the teacher. The script is initially written by the teacher and then, through co-operation, social interaction, the pupil changes the roles, modifies the script in line with his or her abilities, possibilities, and wishes. Their (interpersonal) relationship is of fundamental importance in determining the further progress of that film of life. Through such relationships and learning, a script with a happy ending is produced.

In describing the intelligence of relations (the authors refer to it as relational in- 
telligence, citing the German psychologist Stefan F. Gross.), Brajša, Brajša-Žganec and Slunjski (1999) put emphasis on the behaviour of the child as having a "separate personality", which means that pupils are valued and that their individuality is respected. They need to see interest, sympathy, enthusiasm; they should feel important and should receive special attention in front of other children. There should be no belittling. There should be mutual respect and the teacher should listen to each pupil attentively (Bukowski and Hoza, 1989).

\subsection{The arena of relations between pupils}

As a heterogeneous community, the classroom is an arena of relations. In that arena, one has to "fight" for one's position in the specific hierarchy of personal recognisability and importance. Relations taking place within the arena are to a certain extent a reflection of adult relations. Further, considering that younger children are honest, the relations are sometimes more rigid than is the case with adults who skilfully hide their intentions in relation to other persons. Experiences gained in such an arena of relations leave an imprint on the individual that follows and marks him or her (to a certain extent) further in life. Children who experience trauma and/or abuse by peers (or adults) in school (or outside school) suffer from a certain level of psychological consequences. For this reason, the school should guide curricular activities towards the building of quality relations between pupils. In the field of psychology, the model of peer relations consists of popularity and friendship. A detailed model was developed by Ladd, 1989. With the aim of stepping outside the psychological interpretations of the mentioned components of peer relations, in the text below we emphasise the didactic specificum of encouraging quality peer relations. The teacher has a significant role in developing quality relations between pupils, and such a didactic specificum can be viewed through the prism of the following activities:

- encouraging group work (team work);

- workshops/activities in developing prosocial behaviour.

The importance of group work that is characterised by mutual co-operation and respect, assistance, sharing of responsibility and obligations, and success and failure is recognised from a didactic (methodical) position.
Further, the quality of peer relations is connected with a child's cognitive development, his or her abilities and social competence (Borovečki and Čiček, 1986, 311).

Quality peer relations develop through the encouragement of group work that can be implemented in almost all types of teaching contents. Instruction in this form is a specificum not only for the realisation of teaching tasks/learning outcomes, but also for the development of interpersonal relations between pupils. Pupils project co-operation forms in instruction to their life outside school. The classroom is a heterogeneous setting in which each pupil should fight for and build his or her recognisability, uniqueness. Building such uniqueness and recognisability pushes some pupils towards risky social behaviour, such as verbal and/or physical aggression, defiance, docility, quarrelsomeness, and other externalised (but also internalised) types of behaviour. There is a narrow line between risky social behaviour and acute behavioural disorders. Some pupils cannot find their recognisability in the said behavioural activities but withdraw from their colleagues and manifest internalised behaviours such as anxiety, introversion, absent-mindedness, weepiness, and other behaviours linked to depression. With their absent-mindedness, inactivity, disillusionment, sorrow, suppressed anger or dissatisfaction, some pupils undermine the healthy psychological and physical development characteristic of their age. Although at first such states do not pose a big problem, they are even more dangerous than the behaviour of those pupils who show active behavioural disorders, because they cause the further development of psychological dysfunction.

Adaptation difficulties and behavioural disorders may be a passing but also a permanent characteristic of behaviour and life. Difficulties arise from the inability to find a way of satisfying one's needs and desires in a socially acceptable fashion. Delayed fulfilment of personal needs and the inability to re-direct one's wishes from unacceptable objects to acceptable ones are the main characteristics of difficulties with adaptation and behavioural disorders (according to Greene et al. (2008)). It is precisely group work that serves to fulfil the needs of children so that in their social relationships with their peers they can prove themselves in a socially acceptable manner.

Workshops/activities entailing the development of prosocial behaviour are significant for quality peer relations. Prosocial behaviour or behaviour directed at helping 
others creates behavioural patterns that are characteristic of social competence. Diametrically opposed to prosocial behaviour would be antisocial behaviour. Ma Hing et al. (2007) show that prosocial and antisocial behaviour should be observed in interaction in order to be able to fully understand the nature of social competence. This can be observed from the point of view that the development of prosocial behaviour is connected with the reduction of antisocial behaviour. The research of $\mathrm{Ma}$ Hing et al. (2007), which indicates that a lack of social competence is a significant problem in aggressive children, confirms this. In this sense, these authors state the importance of video feedback in schoolyards to encourage the prosocial behaviour of aggressive pupils. It is obvious that prosocial behaviour encourages pupils' social competence and is an alternative for aggressive behaviour. Ma Hing et al. (2007), as a result of the study on the encouragement of prosocial behaviour in Chinese adolescents, suggest that positive peer interactions, good family settings, and a positive socially-oriented personality increase the prosocial orientation of adolescents.

Curricular activities should include workshops aimed at developing mutual assistance. This would include the detection of pupils, individuals, families, and institutions that need assistance. A plan of activities, a workflow, is then drawn up to provide assistance. By helping others, pupils learn to co-operate, share, empathise, and so on. They embrace moral principles; they learn to understand themselves and others, and they learn not to be egotistical.

The school as an arena of peer relations is imbued with interpersonal relations. In a very early stage of development, children learn how to act and they develop what they learn into certain modalities of their own recognisable behaviour. As they grow, the positions acquired in such an arena of relations are strengthened and they act accordingly. It is of paramount importance for the school, as an arena of interpersonal relations, to supervise and develop the quality of such relations appropriately and in a controlled manner. Later, many difficulties that adults encounter in the way they perceive the world around themtheir uniqueness, goals, purpose-stem to a certain extent from the school arena of peer relations (but also relations with other persons). It is the primary role of the school in developing high-quality mutual relations to develop social competence, which is of vital importance for any society.

\section{MATERIALS AND METHODS}

In view of interpersonal relations, one of the goals of this project is to examine the quality of interpersonal relations between teachers and pupils. As in the introduction to this paper we stressed the importance, role, and the consequences of the quality of relations, the results are important in order to perceive the real "picture" of the quality of relations in our schools.

In line with the empirical part of the project titled "The Curriculum of Social Competences and Relations in School", the sample of interviewees for this paper consists of 432 teachers from 20 towns and 35 primary schools of the Republic of Croatia, and 432 pupils. The structure of teachers based on their subjects is shown in Table 2. For ease of review, the subjects are classified into groups.

Table 2. Field of work of teachers (subjects)

\begin{tabular}{lcc}
\multicolumn{1}{c}{ Fields of work (subjects) } & Number & Percentage \\
\hline Mathematics, informatics & 82 & 18.9 \\
\hline $\begin{array}{l}\text { Languages (foreign languages and } \\
\text { Croatian) }\end{array}$ & 152 & 35.2 \\
\hline $\begin{array}{l}\text { Visual and performing arts (art, } \\
\text { music) }\end{array}$ & 32 & 7.4 \\
\hline History, geography & 47 & 10.8 \\
\hline $\begin{array}{l}\text { Natural sciences (biology, physics, } \\
\text { chemistry, nature) }\end{array}$ & 48 & 11.1 \\
\hline Physical education & 24 & 5.6 \\
\hline Technical culture & 9 & 2.1 \\
\hline Classroom instruction & 7 & 1.6 \\
\hline $\begin{array}{l}\text { External associates, headteachers } \\
\text { (rehabilitator, librarian) }\end{array}$ & 3 & 0.6 \\
\hline Religion & 28 & 6.5 \\
\hline
\end{tabular}

The sample of variables consists of 14 items that examine the level of interpersonal relations between pupils and teachers. It is an ordinal 5-point Likert-type scale: 1- strongly disagree, 2 - disagree, 3 - neither agree nor disagree, 4 - agree, and 5 - strongly agree. We tested the reliability of the scale via the internal consistency method (based on the alpha model), where Cronbach's alpha is 0.921 , which implies high reliability. 
(IJCRSEE) International Journal of Cognitive Research in Science, Engineering and Education Vol. 4, No.2, 2016.

\section{RESULTS}

In view of the 14-item scale used, the main descriptive values are shown in Table 3.

Table 3. Main descriptive values of the scale

\begin{tabular}{|c|c|c|c|c|c|c|c|c|}
\hline \multirow[t]{2}{*}{ Items } & \multirow{2}{*}{$\begin{array}{l}\min \\
\text { stat. }\end{array}$} & \multirow{2}{*}{$\begin{array}{l}\max \\
\text { stat. }\end{array}$} & \multicolumn{2}{|c|}{ mean } & \multirow{2}{*}{$\begin{array}{l}\text { std. } \\
\text { dev. }\end{array}$} & \multirow{2}{*}{$\begin{array}{l}\text { mod } \\
\text { stat. }\end{array}$} & \multirow{2}{*}{$\begin{array}{c}\text { skewness } \\
\text { stat. }\end{array}$} & \multirow{2}{*}{$\begin{array}{c}\text { kurtosis } \\
\text { stat. }\end{array}$} \\
\hline & & & stat. & $\begin{array}{l}\text { std. } \\
\text { error }\end{array}$ & & & & \\
\hline $\begin{array}{l}\text { P10.1 Most teachers in your school respect and acknowledge the } \\
\text { opinion of their pupils }\end{array}$ & 2 & 5 & 4.00 & .035 & .732 & 4 & -.538 & .352 \\
\hline P10.2 Most teachers in your school believe in their pupils & 2 & 5 & 3.94 & .034 & .709 & 4 & -.430 & .287 \\
\hline P10.3 Most teachers in your school support pupils and help them & 2 & 5 & 4.23 & .032 & .655 & 4 & -.429 & -.064 \\
\hline $\begin{array}{l}\text { P10.4 Most teachers in your school find it easy to make pupils } \\
\text { interested in learning }\end{array}$ & 2 & 5 & 3.77 & .034 & .711 & 4 & -.187 &,- 132 \\
\hline P10.5 Most teachers in your school use group work in class & 2 & 5 & 3.84 & .037 & .765 & 4 & -.253 & -.287 \\
\hline $\begin{array}{l}\text { P10.6 Most teachers in your school maintain order and discipline } \\
\text { in class without excessive strictness }\end{array}$ & 1 & 5 & 3.75 & .036 & .742 & 4 & -.386 & .231 \\
\hline $\begin{array}{l}\text { P10.7 Most teachers in your school resolve problems and conflicts } \\
\text { successfully }\end{array}$ & 2 & 5 & 3.89 & .033 & .678 & 4 & -.224 & .014 \\
\hline P10.8 Most teachers in your school have a sense of humour & 2 & 5 & 3.71 & .036 & .744 & 4 & -.161 & -.249 \\
\hline P10.9 Most teachers in your school are in a good mood & 1 & 5 & 3.83 & .037 & .763 & 4 & -.367 & .099 \\
\hline P10.10 Most teachers in your school talk to pupils & 1 & 5 & 4.07 & .030 & .615 & 4 & -.765 & 2.749 \\
\hline $\begin{array}{l}\text { P10.11 Most teachers in your school do not use physical } \\
\text { punishment }\end{array}$ & 1 & 5 & 4.70 & .027 & .564 & 5 & -2.197 & 6.568 \\
\hline P10.12 Most teachers in your school are polite towards pupils & 2 & 5 & 4.42 & .032 & .655 & 5 & -.833 & .271 \\
\hline $\begin{array}{l}\text { P10.13 Most teachers in your school do not use nasty and impolite } \\
\text { words when they are angry at the behaviour of a pupil }\end{array}$ & 2 & 5 & 4.38 & .033 & .694 & 5 & -.831 & .133 \\
\hline $\begin{array}{l}\text { P10.14 Most teachers in your school do not call pupils insulting } \\
\text { names }\end{array}$ & 2 & 5 & 4.40 & .032 & .674 & 5 & -.861 & .350 \\
\hline
\end{tabular}

As evident from Table 3, the values of the measures of central tendency (arithmetic mean and mode) are high, which in view of the polarisation of the scale shows that there is a tendency of higher values in the perception of teachers towards the quality of relations between the teacher and the pupil (4 - agree, 5 - strongly agree). In a word, there is a mildly negatively asymmetrical distribution, which is in line with the higher values of the arithmetic means. In line with this, the distribution of all items deviates from the required normal distribution (Kolmogorov-Smirnov; $\mathrm{p} \leq 0.05$ on all items). Also, in view of the kurtosis of the distribution, these are mostly mild leptokurtic distributions (other than items p10.10 and p10.11 - pronounced leptokurtosis). The other four items are mildly platykurtic (p10.3, p10.4, p10.5, p.10.8).

Considering that the perceptions of teachers concerning the quality of interpersonal relations between them and pupils are mostly positive, it was interesting to see the extent to which they differ from the perceptions of pupils. From the total sample of interviewed pupils ( $\mathrm{N}=2661)$, based on the method of random number (randomisation procedure),
432 were singled out to compare with those of teachers. The items (14 of them) are identical; they were only semantically transformed for teachers and pupils respectively. The comparative values of the arithmetic means for the teacher and the pupil on the scale of quality of interpersonal relations between pupils and teachers are shown in Table 4. 
Table 4. Differences between the arithmetic means of the subsamples

\begin{tabular}{|c|c|c|c|c|c|c|c|c|}
\hline \multirow[t]{2}{*}{ Items } & \multirow{2}{*}{$\begin{array}{c}\begin{array}{c}\text { arith. } \\
\text { mean } \\
\text { (teachers) }\end{array} \\
\text { stat. }\end{array}$} & \multirow{2}{*}{$\begin{array}{c}\text { mod } \\
\text { stat. }\end{array}$} & \multirow{2}{*}{$\begin{array}{c}\begin{array}{c}\text { arith. } \\
\text { mean } \\
\text { (pupils) }\end{array} \\
\text { stat. }\end{array}$} & \multirow{2}{*}{$\begin{array}{c}\text { mod } \\
\text { stat. }\end{array}$} & \multicolumn{2}{|c|}{ t test } & \multirow{2}{*}{$\begin{array}{c}\begin{array}{c}\text { arith. mean } \\
\text { (both } \\
\text { subsamples) }\end{array} \\
\text { stat. }\end{array}$} & \multirow{2}{*}{$\begin{array}{c}\text { Mod of both } \\
\text { subsamples }\end{array}$} \\
\hline & & & & & stat & $\begin{array}{l}\text { stat. } \\
\text { sign. }\end{array}$ & & \\
\hline $\begin{array}{l}\text { P10.1 Most teachers respect and } \\
\text { acknowledge the opinion of their } \\
\text { pupils }\end{array}$ & 4.00 & 4 & 3.30 & 4 & -10.764 & 0.00 & 3.65 & 4 \\
\hline P10.2 Most teachers believe in pupils & 3.94 & 4 & 3.38 & 3 & -8.907 & 0.00 & 3.66 & 4 \\
\hline $\begin{array}{l}\text { P10.3 Most teachers support pupils } \\
\text { and help them }\end{array}$ & 4.23 & 4 & 3.52 & 4 & -11.876 & 0.00 & 3.88 & 4 \\
\hline $\begin{array}{l}\text { P10.4 Most teachers find it easy to } \\
\text { make pupils interested in learning }\end{array}$ & 3.77 & 4 & 2.86 & 3 & -13.702 & 0.00 & 3.32 & 4 \\
\hline $\begin{array}{l}\text { P10.5 Most teachers use group work } \\
\text { in class }\end{array}$ & 3.84 & 4 & 3.09 & 3 & 10.886 & 0.00 & 3.47 & 4 \\
\hline $\begin{array}{l}\text { P10.6 Most teachers maintain order } \\
\text { and discipline in class without } \\
\text { excessive strictness }\end{array}$ & 3.75 & 4 & 3.03 & 3 & -10.589 & 0.00 & 3.39 & 4 \\
\hline $\begin{array}{l}\text { P10.7 Most teachers resolve } \\
\text { problems and conflicts successfully }\end{array}$ & 3.89 & 4 & 3.20 & 4 & -10.347 & 0.00 & 3.55 & 4 \\
\hline $\begin{array}{l}\text { P10.8 Most teachers have a sense of } \\
\text { humour }\end{array}$ & 3.71 & 4 & 3.02 & 4 & -9.365 & 0.00 & 3.37 & 4 \\
\hline $\begin{array}{l}\text { P10.9 Most teachers are in a good } \\
\text { mood }\end{array}$ & 3.83 & 4 & 2.94 & 3 & -13.173 & 0.00 & 3.39 & 4 \\
\hline P10.10 Most teachers talk to pupils & 4.07 & 4 & 3.65 & 4 & -7.252 & 0.00 & 3.86 & 4 \\
\hline $\begin{array}{l}\text { P10.11 Most teachers do not use } \\
\text { physical punishment }\end{array}$ & 4.70 & 5 & 4.32 & 5 & -6.076 & 0.00 & 4.51 & 5 \\
\hline $\begin{array}{l}\text { P10.12 Most teachers are polite } \\
\text { towards pupils }\end{array}$ & 4.42 & 5 & 3.70 & 4 & -11.638 & 0.00 & 4.06 & 4 \\
\hline $\begin{array}{l}\text { P10.13 Most teachers do not use } \\
\text { nasty and impolite words when they } \\
\text { are angry at the behaviour of a pupil }\end{array}$ & 4.38 & 5 & 3.80 & 5 & -8.292 & 0.00 & 4.09 & 5 \\
\hline $\begin{array}{l}\text { P10.14 Most teachers do not call } \\
\text { pupils insulting names }\end{array}$ & 4.40 & 5 & 3.65 & 5 & -10.389 & 0.00 & 4.02 & 5 \\
\hline
\end{tabular}

As evident from Table 4, the values of the arithmetic mean of all items are lower for pupils than for teachers. Item 10.4: Most teachers find it easy to make pupils interested in learning has the lowest value for pupils $(\mathrm{M}=2.86)$, while for teachers, the lowest value is for item 10.8: Most teachers have a sense of humour $(\mathrm{M}=3.71)$. It is interesting that the high perceived quality of interpersonal relations between pupils and teachers coincides with the same items: most teachers talk to pupils, they do not use physical punishment on pupils and are polite to pupils, they do not use nasty and impolite words when they are angry at the behaviour of a pupil, and do not call pupils insulting names. Although it follows from the arithmetic means that the perceived quality of interpersonal relations between pupils and teachers is different-where the pupils hold the relationship to be of lower quality - the said differences were tested via the independent sample t-test. The results of the t-test (Table 4), where the values assume that the equality of variance is not met, confirm statistically significant differences of the arithmetic means with respect to all items, that is, teachers and pupils from the sample are different in terms of the perceived quality of interpersonal relations. It is implicitly concluded from the statistically significant differences on all variables, on the basis of the values of the arithmetic means of the subsample, that pupils hold the quality of interpersonal relations to be lower than teachers. Therefore, although the total level of the quality of interpersonal relations between pupils and teachers is satisfactory, pupils still give a lower score to the quality of interpersonal relations than teachers.

In order to gauge the latent dimensionality of the scale of interpersonal relations between teachers and pupils (on the sample of teachers), a factor analysis (the method of principal components) was used. The collinearity of the substrate of 14 variables of corre- 
lation coefficients is mostly moderate, which indicates a relatively homogenous area, that is, the possibility of the existence of latent dimensions responsible for their mutual variation. Singularity $(r=1)$ or high collinearity $(r>0.90)$ is not evident. The suitability of the matrix for factorisation was tested with the KMO test. The coefficient (KMO) 0.870 shows the high suitability of the matrix for factorisation. Via the Bartless test of sphericity, we tested whether the matrix of correlations is identical to the matrix of identity. Based on the results of the test $(\chi 2=3763.462, \mathrm{df}=91, \mathrm{p}=000)$, it is implied that the correlation matrix is statisti- cally different from the identity matrix, which permits the extraction of factors, that is, the continued implementation of the factor analysis.

According to the Guttman-Kaiser criterion (and Cattell's scree test), two main components that account for $62.0 \%$ of the variance were extracted. Table 5 - Compound Matrices shows the weighting components conducted on the direct oblimin oblique angle rotation with four iterations $(>0.40)$. The weighting components coincide with the coefficient level of individual manifest variables with components.

Table 5. Compound matrices

\begin{tabular}{|c|c|c|}
\hline \multirow{2}{*}{ Items } & \multicolumn{2}{|c|}{ Components } \\
\hline & 1 & 2 \\
\hline P10.1 Most teachers in your school respect and acknowledge the opinion of their pupils & .678 & \\
\hline P10.2 Most teachers in your school believe in their pupils & .738 & \\
\hline P10.3 Most teachers in your school support pupils and help them & .695 & \\
\hline P10.4 Most teachers in your school find it easy to make pupils interested in learning & .813 & \\
\hline P10.5 Most teachers in your school use group work in class & .682 & \\
\hline
\end{tabular}

P10.6 Most teachers in your school maintain order and discipline in class without

excessive strictness

.736

P10.7 Most teachers in your school resolve problems and conflicts successfully

P10.8 Most teachers in your school have a sense of humour 756

P10.9 Most teachers in your school are in a good mood .853

P10.10 Most teachers in your school talk to pupils .805

P10.11 Most teachers in your school do not use physical punishment

.629

P10.12 Most teachers in your school are polite towards pupils

P10.13 Most teachers in your school do not nasty and impolite words when they are angry at the behaviour of a pupil

P10.14 Most teachers in your school do not call pupils insulting names .810

As evident in Table 5, two subscales were generated. The first subscale (SCALE OF DIDACTIC SUPPORT AND INTERACTION) consists of items that mostly relate to the didactic part of the quality of interpersonal relations between pupils and teachers, while the second subscale consists of behaviour (p10-11 to p10-14), which is more characteristic of ROUGH VERBAL AND PHYSICAL TREATMENT between pupils and teachers. The reliability of the subscales was tested via the method of internal consistency under the alpha model: Cronbach $\alpha 1=0.915, \alpha 2=0.865$. Below we examine gender-related differences between teachers in terms of their appraisal of the level of quality of interpersonal relations between them and the pupils. An independent sample t-test was used, under the assumption that the variances are inhomogeneous. The results of the t-test are shown in Table 6. 
Table 6. Results of the t- test

\begin{tabular}{lccc}
\hline \multicolumn{1}{c}{ Components } & $\mathrm{t}$ & $\mathrm{df}$ & $\begin{array}{c}\text { Stat. } \\
\text { significance }\end{array}$ \\
\hline $\begin{array}{l}\text { Didactic support } \\
\text { and interaction }\end{array}$ & 1.702 & 114.364 & 0.092 \\
\hline $\begin{array}{l}\text { Rough verbal } \\
\text { and physical } \\
\text { treatment }\end{array}$ & -0.759 & 110.825 & 0.450 \\
\hline
\end{tabular}

As evident from Table 6 , there is no statistically significant gender difference among teachers in view of the perceived quality of interpersonal relations between teachers and pupils. On both subscales of interpersonal relations (the scale of didactic support and action and the scale of rough verbal and physical treatment), there is no difference among female and male teachers in terms of their perception of quality. However, in view of the disproportionate ratio of female and male participants (76 male teachers, 356 female teachers), we also applied the non-parametric equivalent of the t-test: the Mann-Whitney U test. The values generated as a result of the Mann-Whitney $\mathrm{U}$ test also did not establish any gender differences on either scale $\left(U_{1}=12208, Z_{1}=-1.336\right.$, $\left.\mathrm{p}_{1}=0.182 ; \mathrm{U}_{2}=12625, \mathrm{Z}_{2}=-0.914, \mathrm{p}_{2}=0.361\right)$.

In view of the years of service, the said sample is in the range from less than one year to 45 years of service. Years of work within the education system are often the subject matter of research in view of certain differences and connections. Accordingly, in the draft of the project titled "The Curriculum of Social Competences and Relations in School", one of the aims was to examine such connections. In order to complete the task based on the said sample of teachers, we performed a correlation analysis on the basis of the presented subscales of the perceived quality of interpersonal relations between teachers and pupils (Table 7).

Table 7. Correlations / Spearman Rho

\begin{tabular}{|c|c|c|}
\hline \multirow{2}{*}{$\begin{array}{l}\text { Subscales of the } \\
\text { interpersonal } \\
\text { relations between } \\
\text { teachers and pupils }\end{array}$} & \multicolumn{2}{|c|}{ Years of service } \\
\hline & $\begin{array}{c}\text { Correlation } \\
\text { coefficient } \\
\text { (Spearman/Rho) }\end{array}$ & $\begin{array}{l}\text { Statistical } \\
\text { significance }\end{array}$ \\
\hline $\begin{array}{l}\text { Didactic support and } \\
\text { interaction }\end{array}$ & 0.014 & 0.778 \\
\hline $\begin{array}{l}\text { Rough verbal and } \\
\text { physical treatment }\end{array}$ & -0.101 & $0.037^{*}$ \\
\hline
\end{tabular}

There is a low negative statistically significant correlation between the years of service and the results on the scale of rough verbal and physical treatment between teachers and pupils. Given that the correlation is negative, it is implied that with the years of service the perceived level of rough verbal and physical treatment as appraised by teachers and pupils is lower. In other words, the older the teachers are the lower is their perception of the quality of interaction between pupils and teachers in terms of the rough verbal and physical treatment between pupils and teachers. In view of the subscale of rough verbal and physical treatment between pupils and teachers, such a result on the negative correlation implies that older teachers hold to a higher degree that their colleagues in school use physical punishment, act rudely towards pupils, use nasty and impolite words, and call pupils insulting names, as opposed to the view of their younger peers.

\section{DISCUSSION}

The quality of interpersonal relations in school is a matrix of opportunities (and unknowns) whose values in many aspects affect those participating in the relationship. Interpersonal relations seen through the sphere of interactions are actually singular. Interaction transcends the particular scientific subject matter; it is basically singular to the general laws of the functioning and understanding of the matter (the natural sciences) but also the social sciences. It is evolution par excellence.

Analogously, the school is a place where interpersonal relations are extremely rich. The further development of the child in the academic sense (school results), his or her psychophysical stability and social competence, that is, the totality of competences that society expects from him or her later on, depends on the quality of such relations. For that reason, interpersonal relations must be at the very core of the curriculum. Interpersonal relations in schools must not be just a sideline to the learning process, but the very foundation of the learning process (in the wider context).

The importance of the research of the quality of such relations follows from the pronounced importance of interpersonal relations in school. The aim of this paper also follows accordingly: to research the quality of interpersonal relations between teachers and pupils. On a total sample of 432 teachers involved in the project "The Curriculum of Social Competences and Relations in School", the scale related to the quality of interpersonal relations between teachers and pupils presented higher values of the arithmetic mean. It is implied that the level of the quality of interpersonal relations between teachers and pupils (based on the perceptions of teachers) is high. 
However, with the aim of generating an accurate "picture" of the quality of such relations, we also tested pupils to examine whether their perceived quality of such relations is different. From the total sample of pupils involved in the project $(\mathrm{N}=2661)$, we singled out 432 via the random number method (randomisation procedure) to compare them with the perceptions of teachers. It is evident from the generated results that the pupils' perceived quality of interpersonal relations between teachers and pupils is somewhat lower (weaker) in comparison to that of teachers. This was actually to be expected. It can be concluded from the collective arithmetic means (mod) of the items on the scale of quality of interpersonal relations that the level of quality between pupils and teachers is at a satisfactory level. Still, the quality could be higher, so the results should be interpreted more as a need to develop quality relations between pupils and teachers.

In order to gain insight into the latent dimension of the scale, a factor analysis was conducted (the method of main components). Two components/subscales were extracted. The scale (subscale) of didactic support and interaction consists of items that mostly relate to the didactic part of the quality of interpersonal relations between pupils and teachers, while the scale (subscale) of rough verbal and physical treatment consists of conduct that is more characteristic of rough verbal and physical treatment between pupils and teachers.

Later, the subscales of the quality of interpersonal relations between teachers and pupils were used. Initially we tested the gender difference in view of the level of the quality of interpersonal relations between pupils and teachers based on the perceptions of teachers. It follows from the results of the t-test that there are no differences between female and male teachers in terms of the perceived quality of interpersonal relations on the subscales.

In view of the comprehensiveness of the empirical part of the project, we included an independent variable - years of service, ranging from less than one year to 45 years of service. Given the wide spectrum (comprehensiveness) of the years of service of teachers from the sample, the author used a correlation analysis (Spearman Rho) to show a low negative correlation ( $\mathrm{r}-0.101, \mathrm{p}=0.037$ ) between the subscale of rough verbal and physical treatment and the years of service of teachers. It follows from the items that make up the subscale of rough verbal and physical treatment between teachers and pupils that teachers with more years of service hold to a higher degree that their colleagues in school use physical punishment, act rudely towards pupils, use nasty and impolite words, and call pupils insulting names, as opposed to the view of their younger peers.

In view of the aim of the research (to examine the quality of interpersonal relations between pupils and teachers), the question arises whether the results show a sufficient quality of such relations. If we compare the results of the perceptions of only pupils (and not teachers), then the results are not sufficiently satisfactory. Pupils had the value of mod 3 on a 5-point scale for certain items - such as: most teachers believe in pupils, use group work in class, maintain order and discipline successfully and without excessive strictness, are in a good mood, find it easy to interest pupils in learning-which is actually neutral (they neither agree nor disagree). Naturally, such results indicate an insufficient level of interpersonal interactions between teachers and pupils in terms of the said items. On the other hand, the perceptions of teachers for the same items are higher, that is, the value of mod is 4 (agree).

\section{CONCLUSION}

The result that strongly emphasises the quality of social relations between pupils and teachers and brings together the perceptions of both teachers and pupils is the values on the subscale of rough verbal and physical treatment. Both teachers and pupils assigned the highest value (mod 5: strongly agree) to the quality of relations between pupils and teachers (the subscale of rough verbal and physical treatment between teachers and pupils). The items are as follows: Most teachers do not use physical punishment, do not use nasty and impolite words when they are angry at a pupil, and do not call pupils insulting names.

In conclusion, the results imply that the relations between pupils and teachers are at a satisfactory level, but efforts should be made to improve and develop them further.

\section{ACKNOWLEDGMENTS}

This paper is part of scientific project titled "The Curriculum of Social Competences and Relations in School" carried out within the project accredited by the Faculty of $\mathrm{Hu}$ manities and Social Sciences, Department of Pedagogy of the University of Zagreb. Special thanks to leader of project prof. dr.sc. Vlatko Previsic. 


\section{Conflict of interests}

est.

The author declare no conflict of inter-

\section{REFERENCES}

Andrilović, V., \& Cudina, M. (1988). Psihologija učenja i nastave. Školska knjiga, Zagreb.

Borovečki,Ž., Ciček, M.(1986). Teškoće prilagođavanja i poremećaji ponašanja. In M. Kutanjac (Ed.), Od puberteta do zrelosti (pp. 311-331). Zagreb: Mladost.

Brajša, P. (1995). Sedam tajni uspješne škole. Školske novine, Zagreb.

Brajša, P., Brajša-Zganec, A., Slunjski, E. (1999). Tajna uspješnog roditelja $i$ odgojitelja; [The secret to becoming successful parents and educators] priručnik za rad na sebi namijenjen roditeljima, odgojiteljima, učiteljima i svima koji žele unaprijediti svoj odnos $s$ djecom. Pula: C.A.S.H.

Bratanić, M., Šikić, A., Biondić, I., Pšunder, M., \& Spajić-Vrkaš, V. (2002). Paradoks odgoja: studije $i$ eseji. Hrvatska sveučilišna naklada.

Bukowski, W. M., \& Hoza, B. (1989). Popularity and friendship: Issues in theory, measurement, and outcome. In T. J., Bendt; G. W., Ladd (Eds.), Peer Relationship in Child Development (pp 1545). New York: John Wiley \& Sons.

Furlan, I. (1967). Učenje kao komunikacija; usvajanje znanja, vještina i navika. Zagreb: pedagoško književni zbor.

Glasser, W., \& Jakovlev, B. (1999). Nastavnik u kvalitetnoj školi: Posebne sugestije nastavnicima koji u razredu pokušavaju primijeniti ideje iz knjige Kvalitetna škola. Educa.

Glasser, W., Ana-Mari, G., Hana, Ž., \& Mamary, A. (2001). Svaki učenik može uspjeti. Alinea.

Gossen, D. C., \& Despotović, M. (1994). Restitucija: preobrazba školske discipline. Alinea.

Green, V. A., Cillessen, A. H., Rechis, R., Patterson, M. M., \& Hughes, J. M. (2008). Social problem solving and strategy use in young children. The Journal of genetic psychology, 169(1), 92-112.

Greene, B., Sćurić, L., \& Jurinić, M. P. (1996). Nove paradigme: za stvaranje kvalitetnih škola. Alinea.

Huitt, W. (2003). The information processing approach to cognition: Educational psychology. Interactive valdostaga. GA: Valdosta University.

Jurić, V. (2004). Metodika rada školskoga pedagoga. Školska knjiga.

Juul, J., Jensen, H. (2010). Od poslušnosti do odgovornosti; kompetencije u pedagoškim odnosima. Zagreb: Naklada Pelago.

Klarin, M. (2006). Razvoj djece u socijalnom kontekstu: roditelji, vršnjaci, učitelji-kontekst razvoja djeteta. Naklada Slap.

Klarin, M., Lukić, LJ., Ušljeberka, I. (2003). Kvaliteta interakcije s učiteljicom i ponašanje djeteta rane školske dobi. Zbornik radova; Učitelj-učenikškola. (str.156-165).

Knapp, M. L., \& Hall, J. A. (2010). Neverbalna komunikacija u ljudskoj interakciji. Slap.

Kyriacou, C., \& Jakovlev, B. (2001). Temeljna nastavna umijeća. Educa.

Ladd, G. W. (1989). Toward a further understanding of peer relationships and their contributions to child development. Peer relationships in child development, 1-11.

Ma, H. K., Cheung, P. C., \& Shek, D. T. (2007). The relation of prosocial orientation to peer interactions, family social environment and personality of Chinese adolescents. International Journal of Behavioral Development, 31(1), 12-18.

Marinković, J. (2008). Učiteljstvo kao poziv. Rastakanje pedagogije $i$ potraga za smislom, (Zagreb: Kruzak).

Matijević, M., \& Radovanović, D. (2011). Nastava usmjerena na učenika. Zagreb: Skolske novine.

Miljković, D. (1991). Organizacija nastave i odnosi nastavnika i učenika. Napredak, 132 (3), 238248.

Neill, S., \& Mikulić, G. (1994). Neverbalna komunikacija u razredu. Educa.

O’Reilly, M. F., O’Halloran, M., Sigafoos, J., Lancioni, G. E., Green, V., Edrisinha, C., ... \& Olive, M. (2005). Evaluation of video feedback and selfmanagement to decrease schoolyard aggression and increase pro-social behaviour in two students with behavioural disorders. Educational Psychology, 25(2-3), 199-206.

Previšić, V. (2003). Suvremeni učitelj: odgojitelj-medijator-socijalni integrator. $U$ : Učitelj-učenikškola. Ur. I. Prskalo, S. Vučak, Petrinja, VUŠ $i$ $H P K, 2,13-20$.

Šimić-Šašić, S., \& Sorić, I. (2010). Pridonose li osobne karakteristike nastavnika vrsti interakcije koju ostvaruju sa svojim učenicima? Društvena istraživanja, $19(6$ (110)), 973-994.

Stevanović, M., \& Papotnik, A. (2004). Skola po mjeri učenika. Tonimir. 